\title{
THE FINANCING OF OIL AND GAS TRANSACTIONS
}

\author{
ROBERT E. SULLIVAN*
}

The search for oil is synonymous with the search for funds to finance the activities involved in the exploration and production of oil and gas. This article submits that the uniqueness of oil and gas financing is directly related to the nature, occurrence and production of petroleum and states that oil and gas financing is affected by the stage of development of the reservoir, the nature of oil and gas rights acquired and the extent of government regulation, including securities, conservation and taxation. The stability provided by comprehensive conservation laws has greatly facilitated oil and gas financing by making proven oil reserves an acceptable form of security for loans. The article concludes with a discussion of the effect of taxation on oil and gas financing in the United States.

\section{A. INTRODUCTORY}

Max Ball was right many years ago when he entitled his best seller on the petroleum industry "This Fascinating Oil Business." ${ }^{1}$ The excitement of search, the uncertainty of discovery and the bonanza of success create an "oil fever" for which there is no palliative-much less a cure. When two further ingredients are added-a strong and increasing demand for the product" and the fluctuating alternatives for a grubstake and the money for expansion:-we wonder why more people are not in the oil business. One reason, of course, is lack of money; the other is lack of exposure to the oil virus.

Recent forecasts project a $6.5 \%$ increase in oil consumption in the free world during 1969. The demand for Alberta oil will increase to

- Dean and Professor of Law. School of Law. University of Montana. Missoula, Montana. Author, Handbook of Oil and Gas Law, (1955). Editor, Conservation of Oil and Gas, A Legal History, 1948-58, American Bar Association, Section of Mineral Law $(1960)$.

1 Max W. Ball, This Fascinating Oil Business, (1940); revised by Douglas Ball and Daniel S. Turner, This Fascinating Oil Business, (1965).

"What's ahead for oil and gas this next year? Here's what some of the industrys' best-informed pecple are predicting: Oil consumption $u$ ill go up about $3 \%$ in the U.S. and $6.5 \%$ for all the free world, according to Standard of Cal's Otto N. Miller. He polnts out the free-world increase is slightly below the 5 ycar average of $7.7 \%$, but on a volume basis wlll be larger than the 5 year average. Miller cites 1969 as the year the world's exploration center of gravity may start shifting from the Middle the year the world's exploration center of gravity may start shifting from the Middle hoe Bay discovery is behind his thinking-and much of the thinking about 1969." (Emphasis in orginal) Newsletter Oil and Gas Journal, December 30, 1968.

$:$ The oil industry may be classified along functional lines as exploration, production, processing (refining) and marketing. Each division is a business in the broad sense processing (refining, and marketing. Each division is a business in the broad sense and as a business competes with al other business for investment dollars. The state of the economy is a variable that must be considered when the search for money
to finance operations is begun. What is an attractive investment in one period of the economy may be less attractive in other periods: ".. . with the exception of both further inflation and further government borrowing requirements, bond prices in general have continued to slip and the rallies that have risen to successively higher peaks and yields on long-term government issues have recently been s high as, and in some cases even higher than anything previously recorded since as high as, and in some cases into existence in this country.

an organized bond market came into existence in this country. viduals, corporations or institutions, have become increasingly reluctant to commit their funds to lons-term bonds because of the combined fear of further deterioration in the value of money and the possibility that the market value of such investments will fall. The problems raised by the emergence of this attitude are very disturbing. In practical terms, they can by no means wholly be resolved by a massive switch to equity financing which, in any event, is denied to non-corporate borrowers." Business Review, Bank Cf Montreal, December 20. 1968.

4 Supra, n. 2. 
954,000 barrels a day during January according to one report" and should remain at that figure, at least through the first quarter. The capital requirements of the petroleum industry are difficult to comprehend. For example, the report of the Chase Manhattan Bank issued in December, 1968, entitled "Capital Investments of the World Petroleum Industry, 1967," contains the following introduction:

The Free World's requirements for petroleum are staggering. In 1967, more than 31 million barrels of oil were consumed each day. And the rate of consumption is growing vigorously-the Free World's needs in 1967 were 2.2 million barrels per day greater than in the preceding year. An even larger increase is expected in 1968, and within a decade the consumption of oil may be nearly twice as large.

Clearly, the petroleum industry's existing capital investment is by no means sufficient to accommodate the indicated future demand for oil and natural gas. Every year, the industry has to spend vast sums of money to find new sources of petroleum to replenish depleted reserves. And it must spend even more for refining, transportation, and marketing facilities-to replace worn-out and obsolete equipment and to expand capacity sufficient to assure full satisfaction of the diverse and far-flung markets.

In 1967, the industry spent more than ever before. Its capital expenditures totalled 15.6 billion dollars. And, in addition, it spent 1.2 billion dollars for exploration purposes. The combined outlay was 980 million dollars more than iv 1966 - and nearly 40 per cent more than the industry spent only five years ago.

Such growth creates a domino effect-demand for crude requires expansion of existing facilities which in turn requires financing to support the expansion. And increasing demand stimulates the search for new petroleum deposits which in turn requires financing to support the geological, geophysical and drilling operations that the search for new oil and gas fields requires.

In an elemental sense, financing means finding, procuring and utilizing money for a specified objective. All of the functions are not served by one rerson or agency but in the aggregate it is a specialty with definite procedures and limitations. Patterns have evolved for different industries and have led to the development of theories of property interests, bases for taxation and principles of governmental regulation. Each industry is different but the catalyst is financing and there is a sameness about the finding and the utilization of moneyalbeit for different substances or services. The procuring techniques reflect the uniqueness of the industry and account for a specialty within a specialty-the subject of this paper: "The Financing of Oil and Gas Transactions."

\section{B. PRELIMINARY CONSIDERATIONS}

The uniqueness of oil and gas financing originates in the exploratory and production phases of the industry. Although the capital requirements of other divisions of the industry are greater, conventional financing techniques characteristic of industry generally are utilized. The

\footnotetext{
- "Some first-time purchases of Canadian crude will help kick up the demand for Alberta oil next year. According to Alberta officials Humble will buy $5,000 \mathrm{~b} / \mathrm{d}$ for its Billings, Mont., refinery and $10,000 \mathrm{~b} / \mathrm{d}$ for its new Benicia. Calif., refinery in January. These are two deals, as is Clark's order for $10,000 \mathrm{~b} / \mathrm{d}$ at Blue Island. January. These are two deals, as is Clark's order for $10,000 \mathrm{~b} / \mathrm{d}$ at Blue Island.
Provincial authorities are predicting January's demand for Alberta crude and Provincial authorities are predicting January's demand for Alberta crude and
equivalents will reach $954,000 \mathrm{~b} / \mathrm{d}$ and will stay at that level throughout the first equivalents will reach $954,000 \mathrm{~b} / \mathrm{d}$ and will stay at that level throughout the first
quarter unless hit by new U.S. demands for cutbacks. The demand includes a need for $788,000 \mathrm{~b} / \mathrm{d}$ of light and medium conventional crudes, a record and a volume that may tax Alberta's pipeline facilities." (Emphasis in original.) Newsletter, Oil and Gas Journal, December 30, 1968.

b Copies may be obtained from the Energy Division, Chase Manhattan Bank, New York. New York.

- See also Sullivan, Organization and Financing of Mining Ventures, (1955) 1 Rocky Mountain Mineral Law Institute 451.
} 
nature of petroleum, how it occurs and how it is produced are prerequisites to an understanding of oil and gas financing.

Oil and gas are minerals. They are not found in underground lakes or pools but in the small pore spaces of sandstone or the leached channels of limestone. They are not evenly diffused through wide areas of the subsurface but occur in geological formations known as traps which are formed by movements of the earth's crust or the pinching out of ancient shore lines, sandbars or reefs." It is the jargon of the industry to refer to petroleum deposits as oil and gas reservoirs. But the reservoirs are not large galleries or open containers, but rock-rock which to the eye appears to be solid and impervious.

To be a container of oil and gas, reservoir rock must be poroussandstones average $10-25 \%$ porosity. To permit discharge of the oil and gas through a well drilled into this container, the reservoir rock must be permeable, that is the pore spaces must be inter-connected. But porosity and permeability are insufficient of themselves to obtain production of oil and gas that may be found in the reservoir. Oil is incapable of self-propulsion. It is dependent upon pressures within the reservoir for movement through the reservoir rock to the bottom of the well. These pressures may be provided by the expansion of gas in solution in the oil, by expansion of free gas in a gas cap at the top of the reservoir, or by the expansion of water that may lie below the deposit of oil within the reservoir rock. When the effective pressure is gone, much oil may remain within the reservoir, but it will remain there, unproduced, until effective pressure is provided from some secondary source."

The topography of the earth's surface gives no indication of the presence or absence of underground traps. Even though the existence of underground traps may be determined by geological or geophysical means, there may be no oil or gas-merely water-within the trap. Therefore the search for oil involves the narrowing of wide areas to the most probable locations, and the drilling of a well. For despite the monumental improvements in the science of searching for oil-there is only one uncontrovertible way of discovering it-and that is by drilling a well. Once discovered of course, additional wells can be drilled in the immediate area and the prospects of an additional producing well are much greater than drilling a "rank wildcat."

Another variable in the mosaic of producing oil and gas is the matter of ownership. In their original state, oil and gas do not migrate within a reservoir like "wild animals" or "percolating waters." Neither do they retain a fixed situs like "solid minerals" when a well penetrates the reservoir rock and a pressure differential within the reservoir is created. The movement of oil and gas that results is not impeded or controlled by lines drawn on the surface of the earth to indicate diverse ownership interests. The Rule of Capture ${ }^{10}$ and the Offset Drilling

$\checkmark$ A trap has been defined as "that portion of any mass of adequately porous and permeable rock (a) which is sealed at the top and down the sides by relatively non-porous and impermeable rock and (b) which lies above the intersection of a
horizontal plane passing through the lowest point of complete sealing." Report, horizontal plane passing through the lowest point of complete sealing." Report, Engineering Committee, Interestate Oil Compact Commission, New Orleans, April 14,
1941. A detalled analysis of the origin, occurrence and production
found in Sullivan, Handbook of Oil and Gas Law, 3-38 (1955).

10 Westmoreland and Cambria Natural Gas Co. v. De Witt (1889) 130 Pa. St. 235, 18 A. 724, 725. "Possession of the land, therefore, is not necessarily possession of the gas. If an adjoining, or even a distant, owner drills his own land, and taps your gas, so that it comes into his well and under his control, it is no longer yours, but his." 
Rule $^{11}$ are more rules of convenience than rules of law. But the stability provided by comprehensive conservation laws and the consequent opportunity to preserve ownership interests has made extensive financing of oil and gas practicable.

It has been forecast that 1969 will be the year that "the world's exploration center of gravity may start shifting from the Middle East toward the far northern areas of the U.S., Canada, and Europe."12 Although there are points of difference in Canadian and American law, there is similarity in the objective to be achieved and identity in the resources to be developed, so that a study of financing of oil and gas transactions in the United States may provide ideas and incentive for Canadian entrepreneurs.

\section{THE FINANCING CONTEXT}

The decisions whether and how to finance exploration and producing operations are a reflection of three basic factors: reservoir, rights and regulation. The emphasis on each of these factors will vary, of course, depending upon the objective the party seeks, i.e., is he seeking finances for exploratory or development operations or is he an investor seeking the most advantageous place for his funds.

\section{Reservoir}

Reservoir requirements vary with the stage of the venture. If there has been no discovery of oil, the prospects of a structure should be established to the satisfaction of potential investors. If oil has been discovered, the existence of a reservoir is established but the extentboth in area and thickness-and the characteristics-type of reservoir rock, type of reservoir drive-and estimate of recoverable reserves, are crucial. Each undertaking then, whether wildcat or developmental, requires an analysis of the probable value of the property. This has been defined as the evaluation of an oil property."' An evaluation must include not only reservoir characteristics but also economics. The availability of information will determine the extent of the evaluation but there are several factors that must be considered: general economics, ${ }^{14}$ marketing factors, ${ }^{15}$ operational problems, ${ }^{11}$ costs of drilling and pro-

11 Barnard v. Monongahila Natural Gas Co. (1907) 216 Pa. 362, 65 A. 801, 802. "What. then, can the nelghbor do? Nothing: only go and do likewise. He must protect his own oil and sas. He knows it is wild and will run away if it finds an opening and it is his business to keep it at home."

12 Supra, n. 2.

13 "The primary purpose of the evaluation in the mind of most management is not merely that it presents facts, but that it affords a means of comparing the relative attractiveness of alternative investments or alternative approaches to the same investment. That is, rate of return on an investment is the primary objective. Although reserves and other engineering figures lend support to the conclusions, in the final analysis, they must be considered only the means to an end, and, as such, of secondary importance." Campbell, Oil Property Evaluation 7 (1959).

14 What is the state of the general economy? What is the demand for oil and gas and its derivatives? Is there an oversupply with the result that only a limited market exists?

15 What market is to be served-a local one or at a distance? Are there adequate transportation facilities? If the oil or gas is to be transported to another country are there import quotas or other restrictions on movement? If processing facilities are necessary are they available?

16 Can the well or wells be operated efficiently? Is it a high cost operation because the operator is inexperienced-organized more for drilling and development as contrasted with operation?

$1 i$ Is it a deep well or a shallow one? Is reservoir pressure sufficient to support initial production or is pumping equipment necessary? Must the oil or gas be treated for impurities prior to sale? What work-over costs will be required? 
duction, ${ }^{17}$ reserves, "' rate of production,": salvage value, ${ }^{20}$ and the value of money. ${ }^{21}$ Variables in each instance preclude a high degree of accuracy but the range of probabilities provide a general frame of reference, and if other factors are favorable, the basis for affirmative action. ${ }^{22}$

\section{Rights}

The attractiveness of an investment in oil and gas ventures depends upon the nature of the rights acquired-the ownership interests and the extent to which they are limited or exclusive. To the conventional equity and debt securities such as stocks and bonds must be added interests in the substances themselves, i.e., minerals in place, royalties, calls on production, etc. Such interests may be for varying periods of timefixed term, fixed term plus an additional term of indefinite duration measurable by a future ascertainable event, or for a period that is unlimited in time. Used singly or in combination, these and similar real property interests provide methods of financing that are unique to the oil and gas industry.

The absolute owner of a tract of land has all of the rights recognized by law in both the surface and the minerals. Constructive severance of these ownership interests occurs when there is a conveyance of the minerals and retention of the surface or vice versa. ${ }^{23}$ The severance may be of all of the minerals, limited to specifically named minerals, or merely of the mineral deposits to be found in a specified formation or above or below a specified depth."- The proceeds of the mineral estate, as distinguished from the mineral estate itself are also capable of separate conveyance. These rights to payment of shares of the oil and gas that may be produced are called "royalties".". Minerals or royalties may be conveyed as a described fractional interest,"

is What are the proven reserves? What percentage are recoverable? What additional percentage will be recoverable with pressure maintenance or supplementary recovery methods? Does the extent of the reservoir indicate additional "probable" reserves?

19 Is there a system of government prorntion, i.e.. limitation of production according to market demand? Is rate of production measured by the effeciency of the reservoir? Is the rate economic, i.e., will the income generated from production justify the investment in the oil property?

20 Will equipment have a useful life or be of value for scrap after termination of production? What equipment is recoverable?

21 What is the real value of money now and its relation to real value at the time of recovery? What will be the rate of inflation? What are and will be the rates of taxation? What is the cost of using money in this venture as contrasted with other, of taxation? What is the
different investments?

22 Governmental regulation or inability to secure financing of programs without disposition of property interests that should be retained may be barriers despite other favorable factors in the evaluation.

23 "The owner of the entire estate in land may convey the minerals therein separately from the surface. Conversely, he may convey the surface separately from the minerals. Stated in another way: The owner has the right to sever his land into two estates, and he may dispose of the mineral estate and retain the surface, or he may dispose of the surface estate and retain the minerals. . . . A severance of the mineral of the surface estate and retain the minerals. if i A severance of the mineral estate from the remainder of the land may be effected either by the conveyance of the minerals alone or by the conveyance of the land with a reservation of the
minerals. . . When the mineral estate in land has been severed from the balance of the land there come into existence two separate and distinct estates, each having all the incidents and attributes of an estate in land. . . The mere grant or reservation of minerals in place does not vest the grantee or reserver with any title to the surface. In spite of this, the grant or reservation of minerals carries with it. as a necessary appurtenance thereto, the right to use so much of the surface as may be necessary to enforce and enjoy the mineral estate conveyed or reserved This is because a grant or reservation of minerals would be wholly worthless if the grantee or reserver could not enter upon the land in order to explore for and the grantee or reserver could not enter upon the land in order to explore for and extract the minerals granted or reserved." Harris v. Currie (1943) 142 Tex. 93,176 S.W. (2d) 302, 304 .

24 Texas Company v. Daugherty (1915) 107 Tex. 226, 176 S.W. 717, 719. "It is generally conceded that for purposes of ownership and conveyance... the earth may be divided horizontally as well as vertically, and that title to the surface may rest in one person and title to the strata beneath the surface . . . in another."

2: Burns v. Bastien (1935) 174 Okla. 40, 50 P. 2d 377; Levy, Oil Royalties-A Distinct Species of Property, (1938) 11 So. Cal. L. Rev. 319.

20 E.g., an undivided $1 / 64$ th interest. 
mineral or royalty acres ${ }^{25}$ or a specified number of units. ${ }^{28}$ The latter approaches avoid errors in computation when fractional conveyances in varying sizes are made to different parties.

The oil and gas lease is the outstanding example of a landowner carving out subordinate interests from his ownership and transferring them to another. ${ }^{20}$ The interests transferred are subordinate in the sense that they are not the equivalent of the landowner's rights, and they may terminate and go back to the landowner if the terms of the lease are not complied with. As consideration for the execution of the lease and under the provisions thereof, the landowner retains certain rights: (1) To receive the bonus money paid for the execution of the lease; (2) to receive delay rentals under the terms of the lease; (3) to receive royalties under the terms of the lease; (4) the possibility of reverter in the minerals in the event there is no production during the primary term or in the event production in paying quantities ceases during the indefinite term; and (5) to use the surface so long as he does not interfere with the operations of the lessee thereon. Each of these rights under an oil and gas lease is a separate and distinct interest in real property, which can be conveyed separately..$^{30}$ Different fractional parts of these various interests can be transferred in the same instrument. ${ }^{31}$ If the landowner desires, his entire remaining interest may be transferred, in which event the rights of the purchaser are subject to those of the lessee so long as the lease continues.

The interests acquired under an oil and gas lease may also be conveyed. These interests, and not those of the lessor, are of major importance in oil and gas financing where property interests, as distinguished from equity or debt securities, are utilized. An oil and gas lessee is referred to as the owner of the lease. Under conventional lease forms, his interest is seven-eighths of the oil and gas produced. This is called the working interest to distinguish it from the royalty interest of the lessor. A lessee may transfer his entire interest in the premises under lease, his entire interest in a part of the premises under lease, or a fraction of his rights in the premises, or a part thereof, under lease, for the whole or a part of the remaining portion of the unexpired term of the lease. They may be granted outright by the lessee or reserved in a

27 If the tract contains 640 acres and $1 / 64$ th interest is to be conveyed, it can be described as 10 mineral acres.

2s The 640 mineral acres may be comprised of 100 units each of 6.4 mineral acres. A conveyance of 50 units would transfer an undivided $1 / 2$ interest or 320 mineral acres.

20 Other examples would be a royalty conveyance limited in duration to the term of an existing lease or term mineral deeds or term royalty deeds.

30 "Having leased the realty for oil and gas purposes he was then vested with three distinct and separate interests-(1) the fee simple title to the surface estate, (2) the reserved royalty interest, and (3) the possibility of a reverter of the minerals. conveyed separately and independently of the others." Brown v. Copp (1951) 105 Cal. App. (2d) 1, 232 P. (2d) 868, 871.

31 "It seems to us that many seemingly irreconcilable conflicts could be resolved without resort to oral evidence if the courts and practitioners would recognize that in the same instrument competent parties may grant a fractional interest in the mineral rights, another and different fractional interest in the royalties and another and different fractional interest in the bonuses and rentals, as the Supreme Court did in the Hinkle case above [Hinkle v. Gauntt (1949) 201 Okla. 432, 206 P. (2d) 100]." did in the Hinkle case above IHinkle v. Gauntt (1949) 201 Okla. 43
Mason, Mineral Rights or Royalties, (1951) 22 Okla. B.A.J. 621. 
conveyance of the leasehold. Thus, a lessee may convey production payments, overriding royalties, and undivided interests, ${ }^{32}$ or he may transfer his entire interest in a part of the leased premises by a farm-out agreement. $^{33}$ Although the working interest is an expense bearing interest, i.e., all costs of drilling, equipping and operating are paid by the lessee, interests other than production payments and overriding royalties may be created by the lessee as expense free interests. Examples are net profit interests ${ }^{34}$ and carried interests. ${ }^{35}$

There is great flexibility in the type of interests that may be created. Respective bargaining positions of the seeker and the provider of capital will determine the format of the property interests utilized. Not to be overlooked of course is the concern of oil men to spread their risk. It is preferable to have diverse fractional interests over a broad area than entire interests in a concentrated, more limited area, to avoid loss of the entire investment because of barren structure, loss of pressure or uneconomic deposits.

\section{Regulation}

The third leg of the tripod in the financing context is regulationgovernment regulation. It takes a variety of forms-regulation of the sale of securities, regulation of exploration and production as conservation measures and financial regulation-if that is not too broad a concept 一through taxation.

\section{(a) Securities}

The issuance and transfer of securities are regulated to prevent the frauds previously perpetrated upon the investment public. ${ }^{36}$ In the States it is accomplished through the so-called "blue-sky" laws, whereas on the federal level and with respect to interstate transactions it is accomplished through the Securities Act. ${ }^{37}$ The federal approach is predicated upon a full disclosure of all pertinent facts through the filing of a registration statement with the Securities and Exchange Commission and the tender of a prospectus containing similar information to prospective purchasers. There are three principal types of state regulation: anti-fraud provisions, requirements for the registration of dealers and salesmen and requirements for the registration of non-exempt securities. The assignment of interests in oil and gas are the proper object

32 "An overriding royalty is a certain percentage of the working interest which as between the lessee and the assignee is not charged with the cost of development or production. The oil payment is similar to the overriding royalty, except that the interest of the assignee ceases upon his receiving a certain amount of money or value out of oll or gas produced from a certain percentage of the working interest. The interest commonly spoken of as an 'undivided interest' is an undivided percentage of the working interest, which differs from the oll payment or the overriding royalty in that it is chargeable with its pro tanto share of the cost of development and production." Knight v. Chicago Corporation (1944) $183 \mathrm{S.W}$. (2d) 666, 670 ment and production

s3 In a farm-out the lessee of a large tract transfers or agrees to transfer to a third person the leasehold estate as to a designated area in return for the agreement of the third party to drill a well thereon. See Rex Oil and Gas Co. v. Busk (1953) 335 Mich. 368,56 n.W. (2d) 221.

34 A net profit agreement provides for payment of a specified fraction of the net after all costs of the lessee have been paid. If there is not net profit, there is no right to receive payment.

35 The conventional carried Interest agreement provides that an owner of a part of the working interest will be "carried" for his part of the expenses of drilling. equipping, operating, etc. by the other working interest owner or owners and the latter may recoup this "carried" share of expenses from production norinally payable to the "carried" party, before there is any obligation to pay the "carried" party his share of production.

36 "The object of the law is to protect the public from the dishonesty, incompetence, ignorance and irresponsibility of persons engaged in the business of disposing of securities of uncertain value whereby the inexperienced and confiding are likely to suffer loss." Stewart v Brady (1921) 300 Ill. 425,133 N.E. 310, 317 .

37 48 Stat. 74 (1933): 15; U.S.C. Sec. 77 a et seq. (195i). 
of such regulations by virtue of their inclusion in the definition of "security".3s The fact that they are also interests in land and their sale involves a transfer of real property is immaterial. ${ }^{33}$ The original lease is not a fractional undivided interest and therefore is not within the definition of a security under the federal act. However, the subdivision of the original lease and the sale of fractional parts thereof constitutes an investment contract under the act and is subject to regulation. ${ }^{40}$ The act applies to issuers of fractional undivided interests, i.e., to an owner of such an interest who in turn creates fractional interests therein for the purpose of offering them to the public for sale. ${ }^{41}$

\section{(b) Conservation}

Conservation is not hoarding. The purpose of conservation legislation is the prevention of waste in order to achieve the greatest ultimate recovery of oil and gas ${ }^{42}$ and the protection of the correlative rights of diverse surface owners whose properties overlie a common source of supply: ${ }^{43}$ This requires the preservation and efficient utilization of the energies naturally occurring in the reservoir." In turn, this necessitates a systematic and scientific approach to all problems incident to

38 An oil and gas lease has been held to be a security within the terms of this definition, Herren v. Hollingsworth (1943) 140 Tex. 263,167 S.W. (2d) 735.

The Securities Act includes in the definition of seeurity ".. fractional undivided Interest in oil, gas, or other mineral rights. 15 U.S.C. Sec. 77b (1) (1951). Under some circumstances an oil and gas lease falls within this definition. S.E.C. v. C. M. Joiner Leasing Corp. (1943) 320 U.S. 344, 64 S. Ct. 120, 88 L.Ed. 88.

39) Morello v. Metzenbaum (1944) 25 Cal. (2d) 494, 154 P. (2d) 670-fractional part of landowners royalty: Cosner v. Hancock (1941) 149 S.W. (2d) 239 (Tex. Civ. App.) - oil payment.

40 An investment contract for purposes of the Securities Act has been defined as ". a contract, transaction or scheme whereby a person invests his money in a common enterprise and is led to expect profits solely from the efforts of the promoter or a third party, it being immaterial whether the shares in the enterprise are evidenced by formal certificates or by nominal interests in the physical assets employed in the enterprise." (Emphasis added.) S.E.C. v. W. J. Howey Co. (1946) 328 U.S. 293, $66 \mathrm{~S}$. Ct. $1100,90 \mathrm{~L}$. Ed. 1244. Leases may consitute securities within the meaning of this definition if the promoter promises to drill a well in the vicinity which, if successful, will increase the value of the leasehold estate.

41 For a discussion of who is an issuer in such a casé, see Federal Trade Commission, Security Act Release 185 (1934).

42 "Conservation consists in the prevention of reasonably avoidable physical waste, underground and aboveground, in efficient recovery and processing, in increasing the yield." Buckley, Petroleum Conservation 6 (1951).

43 "The broad objective of this system is to prevent the waste of oil and gas, both under and above ground, in a manner which protects the correlative rights of the property owners. ... Numerous regulations governing the location, spacing, drilling. property owners. . . Numerous regulations governing the location, spacing, driling. operation, and abanded to achieve these ends. However, the most important regulation, without which most of the others would accomplish little, is restriction of the rate of production, of both individual wells and pools. Control of production rate is absolutely essential to conserve reservoir energy, to effect efficient displacement, and to protect correlative rights." Baker, Achievements and Unsolved Problems in Oil and Gas Conservation, a paper presented at the southwestern district meeting of the A.P.I. Division of Production, March 10, 1949.

"is on the use by one | surface owner whose land overlles a common source of suppiyj of his power to seek to convert a part of the common fund to actual possession may result in an undue proportion being attributed to one of the possessors of the right to the detriment of the others, or by waste by one or more to the annihilation of the rights of the remainder. Hence it is that the legislative power, from the peculiar nature of the right and the objects upon which it is to be exerted, can be manifested for the purpose of protecting all the collective owners, by securing a just distribution, to arise from the enjoyment. by them, of their privilege to reduce to possession, and to reach a like end by preventing waste." Ohio Oil Co. v. State of Indiana (1900) 177 U.S. 190, 210, 20 S. Ct. 576, 44 L. Ed. 729.

4t "The essence of modern conservation is so to utilize the natural energy originating in the reservolr and its environs as to secure the maximum amount of economically recoverable oil from each pool. It is only by control of the reservoir as a whole that such an attainment is possible. Only within recent years has it been realized that the underground forces existing in an oil reservoir and its environs or forces which can be supplied thereto can be employed actually to control the movement of oil in the reservoir. With this realization and the knowledge associated therewith has come the discovery that there are both effective and ineffective ways of utilizing has come the discovery that there are both effective and ineffective ways of utilizing the underground energy, that by its proper." use and control it is possible to recover Interstate Oil Compact Commission Quarterly Bulletin 61 (July, 1944). 
production. $^{45}$ The scientific basis for conservation has already been established. The success of the scientific approach has been demonstrated by the accumulation of corroborative engineering data in recent years.

Conservation of oil and gas is a cooperative undertaking. ${ }^{40}$ In actual operation, conservation involves the interrelation of three groups of principles: engineering, which established the necessity for it; legal, which provided the framework of it; and economic, which determined the feasibility of it. In the exercise of regulatory authority over the production of oil and gas, state conservation commissions apply technical principles of conservation ${ }^{*-}$ that may be classified as follows:

1. Spacing-restriction upon the number and location of wells;

2. Drilling Operations - regulation of drilling and completion practices;

3. MER-restriction of production to the maximum (or most) efficient rate;

4. Proration-allocation of production between separately owned tracts within a common source of supply;

5. Ratios-limitation of production in excess of an established gas-oil and water-oil ratio;

6. Volumetric Withdrawals-restriction of production of gas, oil or water to prevent excessive localized withdrawals.

The differences in the physical characteristics of oil and gas require regulations that differ as to detail, although the underlying principles are the same. The spacing of wells is a good example. In the case of gas wells, spacing of 320 and 640 acres may be adequate to effectively drain an area; whereas, in the case of oil wells, spacing of 40 acres or less may be required.

Limitations on the number of wells and the amount of production and the allocation of permitted production on the basis of market demand are important factors in any evaluation of pay-out time for an investment. The stability provided by comprehensive conservation laws, however, has made proven oil reserves in the ground a bankable commodity-an acceptable form of security for loans. ${ }^{48}$ The problem of dividing

45 "The theory and principle upon which the modern conservation legislation is enacted is to require a uniform use of the natural gas which constitutes the reservoir pressure by which the oil is lifted from the subterranean formations of the earth to the earth's surface. Such lesislation must be predicated upon the engineering princlple. well demonstrated and well recognized by the courts as well as by the various state departments charged with the duty of enforcing the conservation statutes, rules and regulations of such state, that the most efficient use of the reservoir energy would result in the largest ultimate recovery of oil from the oil bearing sand." Moses, The Constitutional, Legislative and Judicial Growth of Oil and Gas Conservation Statutes, (1941) 13 Miss. L.J. 353, 379.

46 "The key to the whole is co-operation, among producers, between producers and royalty, owners, between the industry and state regulatory agencies, and among the states." Buckley, Petroleum Conservation 14 (1951).

17 For a discussion of the mechanics of conservation, see Survey of the Administration of Oil and Gas Conservation, VII Interstate Oil Compact Quarterly Bulletin 65 (Sept., 1948).

is "The passage of the conservation laws enabled banks to establish with reasonable accuracy, the number of barrels yet to be produced from a given area after it has been proven to be productive. Those unproduced but proven reserves of oil, in the minds of oil bankers, is the inventory of the operator in storage in the ground just the same as the inventory of a merchant might be in a warehouse. The rate of withdrawing the inventory from the ground storage and selling it at the market price was still a hazardous factor unless others having access to the same storage in the ground withdraw at the same rate as the operator whose property was pledged to a bank; and this enforced withdrawal from the common pool eliminated this hazard.

"The enactment of conservation laws has contributed immeasurably to giving assurances that adjoining leasehold owners will not drain away from the pledged 
ownership of oil and gas in a common reservoir where there are different property owners is no longer a matter of chance under the Rule of Capture. Proration (allocation of production) is a governmentally enforced division among wells that have been drilled into the reservoir. A contractual agreement among owners is possible through an approved unit operation plan for all or a part of a reservoir.

In addition to providing stability of collateral for loans and a measure of the amount of oil various owners may produce from the reservoir, conservation has stimulated some self-financing. For example, in large unit operations, production may be large enough to absorb all costs of current and developmental operations thus obviating at least short term financing. Under joint operating agreements and where acreage has been pooled to form spacing or production units, the share of costs of owners who do not approve a drilling program, may be charged against their share of production.

\section{(c) Taxation}

An evaluation of the acquisition or disposition of oil and gas property interests must include an analysis of the tax consequences. Care must be exercised to avoid loss or postponement of property rights resulting from excessive emphasis on tax considerations. However, tax advantages are important in choosing among several alternative methods of financ.ing and may be the difference in choosing oil investments in lieu of other opportunities.

There are several elements in the federal income tax that must be considered: depletion, intangibles, capital gain, and loss upon abandonment.

The production of oil and gas is an income-producing operation and not a sale." In common with other minerals, oil and gas are wasting assets, i.e., production reduces the quantity remaining in the reservoir and eventually the deposit is exhausted. Consequently, there is a partial return of capital as well as a realization of income, with each unit of production." To compensate the taxpayer for this continuing return of capital in the form of income from oil and gas operations, the tax laws allow a credit against gross income called the depletion allowance." It is distinguished from the allowance for depreciation in that it relates to a decrease in quantity and estimated value of natural resources that cannot be replaced, whereas depreciation refers to a decrease in value, through use, of replaceable assets. ${ }^{.2}$

property a greater proportion of the underground inventory than belongs to that pledged to the bank for credit. This period of eighteen years since 1932 has each year attracted more lenders of money to the oil industry because of the apparent equitable enforcement of the proration laws. If the system is not always equitable (and there is some indication that some producers frequently question such inequitableness), it is nevertheless from a lender of money standpoint, equal as to adjoining ableness), it is nevertheless from a lender of money standpoint, equal as to adjoining
properties; and hence, the property used as a security will not be inequitably depleted properties; and hence, the property used." as a security will not be inequitablly depleted pamphlet published and avallable for distribution from the Interstate Oil Compact Commission (1951).

to "Oll and gas reserves, like other minerals in place, are recognized as wasting assets. The production of oil and gas, like mining of ore, is treated as an income-producing operation, not as a conversion of capital investment as upon a sale, and is said to resemble a manufacturing business carried on by the use of the soil." Anderson $v$. resemble a manufacturing busing

so U.S. v. Ludey 274 U.S. 295. The theory of the allowance for depletion is that as the product is sold a gradual sale is being made of taxpayer's capital investment in the property.

51 Int. Rev. Code of 1954, Sec. 611-613.

52 Lynch v. Alworth-Stephens Co. (1925) 267 U.S. 364. 
The depletion allowance is not available unless the taxpayer has an "economic interest" in an oil and gas deposit."3 There is such an interest where "the taxpayer has acquired, by investment, any interest in the oil in place and secures, by any form of legal relationships, income derived from the extraction of the oil, to which he must look for a return of his capital.".i4 The elements of this definition have been construed in subsequent cases. Thus an "investment" does not require the payment of a consideration for the acquisition of the interest." An "interest in the oil in place" means some form of property interest. Thus mere ownership of shares in a corporation which owned oil and gas properties is not ownership of an interest in oil and gas in place. in A processor of wet gas produced in association with oil who contracts to take all of the gas and account to the producer for a share of the proceeds does not have an interest in the oil and gas in place. ${ }^{i \pi}$ The property interest required does not contemplate ownership of the oil and gas in place." Thus a landowner who executes an oil and gas lease which under local law passes title to the minerals in place, retains nonetheless an economic interest and is entitled to the depletion allowance on the bonus and royalties received under the lease.:" The lessee under an oil and gas lease, or the working interest owner as he is sometimes called, is also the owner of an economic interest and entitled to the depletion allowance on oil that is attributed to his interest." There is a sufficient property interest to support the depletion allowance whether the lessee is considered an owner of the minerals in place or merely of a profit $\dot{a}$ prendre-a right to go on the premises and remove the minerals. ${ }^{\text {i1 }}$ Assignees of a share of production, whether their rights are limited as to time or coterminous with the life of the lease, have a property interest that will support the depletion allowance on the production that is attributable to their interest.": "Income derived from the extraction of the oil" has been construed to mean income derived solely from the production of oil and precludes additional security for payment

53 Palmer v. Bender (1933) 287 U.S. 551.

54 Id.

:5 "The cost of that investment to the beneficiary of the depletion .... is unimportant. Depletion depends only upon production. It is the lessor's, lessee's, or transferee's 'possibility of profit' from the use of his rights over production, 'dependent solely upon the extraction and sale of the ofl'-which marks an economic interest-in the upon the extraction and sale of the ofl -which marks an econom
oll." Burton-Sutton Oil Co. v. Commissioner (1946) 328 U.S. 25, 34 .

st Helvering v. O'Donnell (1938) 303 U.S. 370. "The ownership of the oll and gas properties was in the corporation."

57 Helvering v. Bankline Oil Co. (1938) 303 U.S. 362 " . the phrase 'economic Interest' is not to be taken as embracing a mere economic advantage derived from production. through a contractual relation to the owner, by one who has no capital investment in the mineral deposit. . . Undoubtedly, the respondent through its contracts obtained an economic advantage from the production of the gas, but that is not sufficient. The controlling fact is that respondent had no interest in the gas in place. Respondent had no capital investment in the mineral deposit which suffered depletion and is not entitled to the statutory allowance."

is Palmer v. Bender (1933) 287 U.S. 511 “. . . the lessor's right to a depletion allowance does not depend upon his retention of ownership or any other particular form of legal interest in the mineral content of the land. It is enough if by virtue of the leasing transaction he has retained a right to share in the oil produced. If so, he has a economic interest in the oil, in place, which was depleted by production."

:n Burnet v. Harmel (1932) 287 U.S. 103; Banker's Pocahontas Coal Co. v. Burnet (1932) 287 U.S. 308.

iv Helvering v. Twin Bell Oil Syndicate (1934) 293 U.S. 312

(i1 For a discussion of the nature of the lessee's interest in the so-called "ownership" and "non-ownership" states (relating to the theory of ownership of oil and gas in the earth), see Sullivan, Handbook of Oil and Gas Law 87 (1955).

6. Palmer v. Bender (1933) 287 U.S. 551-overriding royalty; Thomas v. Perkins (1937) 301 U.S. 655 - oil payment. 
such as a lien on non-mineral properties. ${ }^{13}$ If the taxpayer may look for a return of his capital to a personal obligation or to a lien against property, in addition to the possibility of production of the minerals, he has no economic interest and is not entitled to the depletion allowance."it The allowance must be apportioned among the owners of the several economic interests in the property in order to avoid double depletion, i.e., two taxpayers taking the allowance on the same item of gross income or on a part thereof.:":

A separate computation of depletion is required for each oil and gas "property". The term "property" is defined as "each separate interest owned by the taxpayer in each mineral deposit in each separate tract or parcel of land." Separate properties are acquired where there is no unity of time, ${ }^{\text {is }}$ of interest, ${ }^{\text {iD }}$ of transferor ${ }^{i 0}$ and of location. ${ }^{i 1}$ Thus the acquisition of interests in different mineral deposits, although within the same tract of land, creates separate properties. $\because$ The acquisition of dissimilar interests, e.g., a royalty and a production payment, in the same tract of land creates separate properties. ${ }^{i 3}$

In determining the manner and the extent to which the depletion allowance may be taken, it is necessary to establish a basis for the property. Basis is the value, in terms of money, of a particular item of property owned by a taxpayer. In its elemental or unadjusted state, it is frequently equated with cost. ${ }^{-1}$ Basis is a changeable thing because

o3 Anderson v. Helvering (1940) 310 U.S. 404. "The reservation of an interest in the fee, in addition to the interest in the oll production, however, materially affects the transaction. Oklahoma City Company is not dependent entirely upon the production of oil for the deferred payments; they may be derived from sales of the fee title to the land conveyed. It is clear that payment derived from such sales would not be subject to an allowance for depletion of the oil reserves, for no oil would thereby have been severed from the ground; an allowance for depletion upon the proceeds of such a sale would result, contrary to the purpose of Congress, in a double deduction-first, to Oklahoma City Company; second to the vendee-owner upon the production of the oil."

04 Id.

ti: Treas. Reg. 1.611-1, 1.613-1; Helvering v. Twin Bell Oil Syndicate (1934) 293 U.S. ". for the purpose of computation 'gross income from the property' means gross income from production less the amounts which the taxpayer was obliged to pay as royalties. The apportionment gives respondent $271 / 2$ percent of the gross income from production which it had the right to retain and the assignor and lessor respectively $271 / 2$ percent of the royalties they receive. Such an apportionment has regard to the economic interest of each of the parties entitled to participate in the depletion allowance." The apportionment of the deduction (percentage depletion) between the several owners of economic interests in a mineral deposit will be made as provided in paragraph (c) of Section 1.611-1.

(iti Int. Rev. Code of 1954, Sec. 614 (a)

(;) Treas. Reg. Section 1.614-1(a) (2). "The term 'interest" means an economic interest in a mineral deposit. The lerm includes working or operating interests, royalties, overriding royalties, production payments and net profits interests."

is Taxpayer acquires an undivided share of the working interest in oil and gas lease. Some time later and from the same assignor he acquires the remaining share of the working interest in the same lease. The taxpayer thereafter owns two separate mineral interests, each of which is a separate property. Treas. Reg. 1.614-1 (a) (3).

(i) "A taxpayer owns a tract of land under which lies one mineral deposit. The taxpayer operates a well on part of the tract and leases to another operator the mineral rights in the remainder retaining a royalty interest therein. The taxpayer thereafter owns in the remainder retaining a royalty interest therein. The taxpayer thereafter owns Reg. 1.614-1 (a) (5) Example 3 .

io "A taxpayer conducts mining operations on eight tracts of land as a single unit. He acquired his interests in each of the eight tracts from separate owners. Even if each tract of land contains part of the same mineral deposit. the taxpayer owns eight separate mineral interests each of which constitutes a separate property." Id.

it "A taxpayer acquires from a single owner, in a single deed, three noncontiguous tracts of mineral land for a single consideration. Even if each tract contains part of the same mineral deposit, the taxpayer owns three separate mineral interests of the same mineral deposit, the taxpayer own." Id. Example 4.

each of which constitutes

73 Id. G.C.M. 22332, 1941-1C.B, 228-simultaneous assignment of dissimilar interests in the same instrument; Herndon Drilling Company (1946) 6 T.C. 628, nonacq. 1946-2 C.B. 6 .

if "In general, the basis of property is the cost thereof. The cost is the amount paid for such property in cash or other property. This general rule is subject to exceptions. . Treas. Reg. 1-1012-1(a). 
of improvements or losses to property or because of a recovery of a part of the cost through allowances such as those for depletion or depreciation. This change is expressed in the concept of adjusted basis. $i:$ Thus the basis must be adjusted upwards where there have been expenditures that have improved the property.": Conversely, the basis must be adjusted downwards where the taxpayer has reduced his cost or basis by deductions from income of various allowances permitted under the revenue laws. :- There are detailed provisions in the internal revenue code and regulations specifying how adjusted basis shall be determined."

The purpose of determining the adjusted basis is to provide a starting point in the computation of tax that may be due upon the transfer or disposition of property and to measure the extent to which allowances, such as those for depreciation and cost depletion, may continue to be available. Thus, there may be a gain or a loss upon the sale of the property, $: "$ or the owner may have taken deductions for depreciation or depletion and these must be considered in determining whether he has recovered his cost-his basis-in the property." The amount subject to tax is what remains after the taxpayer has subtracted his adjusted basis (and other permissible deductions), where the property is sold, or after the taxpayer has deducted an aliquot part of his income measured by the permissible allowances such as those for depreciation or depletion, where the property is income producing and is retained.

Implicit in the concept that the capital investment in a wasting asset is recovered through the depletion allowance, is the requirement that the extent of this investment-the basis of the property must be ascertainable at all times. Thus, a valuation must be placed upon the mineral interest"1 and this valuation-this basis-must be adjusted downward to reflect the amount of depletion that is taken annually. The current value of the mineral interest after deductions have been taken for depletion and other allowances is called the adjusted basis of the property. ${ }^{82}$

7.) "The adjusted basis for determining the gain or loss from the sale or other disposition of property is the cost or other basis prescribed . i adjusted to the extent
provided . . for under applicable provisions of the internal revenue laws." Treas. provided $1-1101-1$.

70 "The cost or other basis shall be properly adjusted for any expenditure, receipt loss or other item properly chargeable to capital account, including the cost of improvements and betterments made to the property. . . . Example. A, who makes his returns on a calendar year basis, purchased property in 1941 for $\$ 10,000$. He subsequently expended $\$ 6,000$ for improvements. Disregarding for the purpose of this example the adjustments required for depreciation, the adjusted basis of the property is $\$ 16,000$. If A sells the property in 1954 for $\$ 20.000$, the amount of his gain will be $\$ 4,000 . "$ Treas. Reg. $1-1016-2(a)(b)$. The amount of tax paid on this
$\$ 4,000$ gain is determined by the rate or per cent that is specified elsewhere in the $\$ 4,000$ gain is determined by the rate or per cent that is specified elsewhere in the 7 Internal Revenue Code.

7 ". the cost or other basis of the property shall be decreased for exhaustion, wear and tear, obsolescence, amortization and depletion. . . Example. An asset was purchased January 1, 1950, at a cost of $\$ 10,000$. The useful life of the asset is ten years. It has no salvage value. Depreciation was deducted and allowed for 1950 to 1954 as follows. . Total amount allowed $\$ 3,500$. [The adjusted basis is $\$ 6,500(\$ 10,000-\$ 3,500)$ I." Treas. Reg. 1-1016-3(a).

is "Section 1016 and Sections $1.1016-2$ to 1016-10, inclusive, contain the rules relating to the adjustments to be made to the basis of property to determine the adjusted basis as defined in Section 1011." Treas. Reg. 1016-1.

io If there is no change in basis, the gain or loss would be measured by the difference between the basis at time of acquisition and the basis at time of sale. If deductions have been taken that reduce the basis the gain upon a sale of the premises would be greater.

so The nature of this limitation is illustrated by the allowance for cost depletion which is no longer available when the adjusted basis of a mineral interest reaches zero. This is not to say that depletion may no longer be taken. Percentage, as distinguished from cost. depletion is still available because it is measured by gross income from the property and not by cost.

s1 "In the case of any mineral property the basis for cost depletion does not include amounts representing the cost or value of land for purposes other than mineral

production." Treas. Reg. 1.612-1(b) (1).
s2 Int. Rev. Code of 1954, Sec. $1016(\mathrm{a})(2)$. 
There are two methods for the computation of the depletion allowance-cost depletion ${ }^{* 3}$ and percentage depletion. ${ }^{-1}$ So long as there is unrecovered basis in the mineral interest, the taxpayer must compute the depletion allowance under both methods and claim the larger of the two amounts.": The rationale for this apparent inconsistency in the tax laws was explained in the case of Producers Oil Corporation v. Commissioner as follows: ". . . the larger depletion serves to reduce the remaining basis and to increase a taxable gain or reduce a tax-reducing loss in the future.": Only one of the alternative methods may be used for the same property for the same taxable year."i Production of oil and gas is insufficient; there must be a sale before the depletion allowance may be computed." Thus the allowance is not available to either a lessor or a lessee for that portion of the produced oil and gas that is consumed in the operation of the property or that is produced but unsold at the end of the taxable year.:"

The depletion allowance does not expire when the basis of the mineral interest is adjusted to zero because percentage depletion is based upon gross income from the property and not upon cost."' However, the adjusted basis of an oil and gas property cannot be reduced below zero even though percentage depletion allowances exceed the original cost of the property:" A negative basis is not recognized, although the allowances in excess of basis will be applied to reduce the recoverable depletable cost of any subsequent capital additions to the property."' The same accounting methods used in the computation of income for other tax purposes must be used in the computation of the depletion allowance. ${ }^{.33}$ The burden of proving that depletion is allowable is upon the taxpayer." ${ }^{34}$

s3 Int. Rev. Code of 1954, Section 611, 612.

s4 Id., Section 611, 613.

65 Id., Section 613; Treas. Reg. 1.611-1 (a) (1): Commissioner v. I. A. O'Shaughnessy Inc. (1941) 124 F. (2d) 33-cannot deduct all of cost from first production and take percentage depletion.

86 (1940) 43 B.T.A. 9.

87 Munger et al. v. Commissioners 14 T.C. 1236.

88 Treas. Reg. 1.611-2(a) (2)-cost depletion; 1.613-3(a)-percentage depletion.

so Roundup Coal Mining Co. (1953) 20 T.C. 388; LeDanois Land and Stone Co. v. Commissioner (1954) 215 F. (2d) 475-royalty owner disallowed allowance where lease provided for use of oil and gas as fuel and for the deduction of the amount used before royalty was computed.

oo Louisiana Iron and Supply Company, Inc. v. Commissioner (1941) 44 B.T.A. 1244. acq. 1941-2 C.B. 8. "The substance of the argument of the respondent is that percentage depletion may not be taken on property which has no basis for gain or loss and for cost depletion in the hands of the taxpayer. He says that the whole purpose of the depletion deductions is to return the cost of the property tax-free to the owner and when cost has been returned by any method. no further deductions for depletion are proper. Percentage depletion, however... is not based on cost. It is an abritrary allowance fixed at $271 / 2$ per centum of the gross income from It is an abritrary allowance fixed at . The $1 / 2$ per centum of the gross income from the property during the taxable year. The words of the statute and the legislative
history do not justify the contention of the respondent that percentage depletion is history do not justify the contention of the respondent that percentage depletion is It is possible, and not unusual, for a taxpayer to recover tax-free, through percentage depletion, an amount greater than the cost of the property. [Citing cases] It follows that a taxpayer may recover a larger amount tax free through depletion than he could through a sale or other disposition of the property. The statute ignores all such inequalities and allows the deduction regardless of whether or not cost has been recovered." And see Rowan Drilling Co. v. Commissioner (1942) 130 F. (2d) 62; Burton-Sutton Öil Co. v. Commissioner (1946) 328 U.S. 25.

01 Beulah B. Crane (1947) 331 U.S. 1: G.C.M. 22239, 1940 C.B. 105: Revenue Ruling 54-421, 1954-2 C.B. 162. "After the basis is adjusted to zero, there remains no further basis of the property which can be further adjusted."

92 Revenue Ruling 54-421, 1954-2 C.B. 162. “. . a any percentage depletion allowances made after its adjusted basis has been reduced to zero should be applied against the cost of any subsequent capital additions to the property in determining the the cost of any subsequent capital addint adjusted basis of the property."

03 Treas. Reg. 1.611-2(a) (2).

94 F-K Land Co. v.Commissioner (1937) 90 F. (2d) 484; Wilson v. Commissioner (1936) 82 F. (2d) 1023. 
Cost depletion for a particular taxable period is determined by a specified formula." It may be expressed as follows: Cost depletion allowable $=\frac{\text { adjusted basis }}{\text { units remaining }} \times$ units sold. Adjusted basis refers to the basis of the property at the end of the taxable period, reduced by the amount of depletion for previous years but not the current year, and increased by any additions that have been made to the depletable property during the current year."1 Units remaining refers to "the number of units of mineral remaining at the end of the period to be recovered from the property (including units recovered but not sold) plus the 'number of units sold within the taxable year. . . ." A A determination of the number of units sold depends upon whether the taxpayer reports his income on a cash or an accrual basis. If on a cash basis it "includes units for which payments were received within the taxable year although produced or sold prior to the taxable year, and excludes units sold but not paid for in the taxable year.":14 If on an accrual basis, it is "determined from the taxpayer's inventories kept in physical quantities and in a manner consistent with his method of inventory accounting."'s!

It is important to recognize that cost depletion for purposes of computing income tax usually differs from cost depletion for purposes of the accounting records of the taxpayer. This results from the requirement that the taxpayer must take the higher of cost or percentage depletion.' '"' In a year when percentage depletion is taken, the adjusted basis for cost depletion will be reduced by that amount, whereas the book value of the mineral property will be reduced only by the cost depletion allowable. For purposes of determining total earnings and profits of a corporation, where depletion is involved, cost depletion and not percentage depletion must be used."'1

In the case of oil and gas wells, percentage depletion is computed on the basis of $271 / 2$ per cent of the gross income from the property, but not to exceed 50 per cent of the taxpayer's taxable income from the property computed without the allowance for depletion..$^{102}$ This is merely an alternative method for the computation of depletion and does not extend the allowance to owners of property interests who are not en-

$\therefore$ Treas. Reg. 1.611-2(a) (1). "After the amount of such |adjustedl basis applicable to the mineral property has been determined for the taxable year, the cost depletion for that year shall be computed by dividing such amount by the number of units of mineral remaining as of the taxable year. . . and by multiplying the depletion unit, so determined, by the number of units of mineral sold within the taxable year. . In the case of natural gas wells where the annual production is not metered and is not capable of being estimated with reasonable accuracy, an alternative method of computing the cost depletion allowance is specified in Treas. Reg. 1.611-2(a) (4).

!f; Int. Rev. Code of 1954, Sec. 612.

j) Treas. Reg. 1.611--2 (a) (3).

Ix Treas. Reg. 1-611-2(a) (2) (i).

!s Treas. Reg. 1.611-2(a) (2) (ii).

Iou Int. Rev. Code of 1954, Sec. 613; Treas. Reg. 1.611-1 (a) (1).

111) Treas. Reg. 1.312-6(c) (1). "In the case of a corporation in which depletion or depreciation is a factor in the determination of income, the only depletion or depreciation deductions to be considered in the computation of total earnings and profits are those based upon cost. - . Thus, discovery or percentage depletion under all revenue acts for mines and oil and gas wells is not to be taken into consideration in computing the earnings and profits of a corporation."

t1\% Int. Rev. Code of 1954. Section 613; Treas. Reg. 1.613-1. " . . In no case shall the deduction for depletion computed under this section be less than the deduction computed upon the cost or other basis of the property provided in section 612 and the regulations thereunder." 
titled to cost depletion. ${ }^{103}$ "Gross income from the property" is defined in the regulations as "the amount for which the taxpayer sells the oil or gas in the immediate vicinity of the well". ${ }^{104}$ If transportation or processing takes place before sale, gross income is defined as the "market or field price of oil or gas before conversion or transportation. ${ }^{10 \pi}$ Gross income from the property refers to the sale of oil and gas as it is produced and not to the sale of an economic interest in the land. In the later case, the proceeds are not subject to the depletion allowance. ${ }^{10 i}$ The "property" for computation of depletion means "each separate interest owned by the taxpayer in each mineral deposit in each separate tract or parcel of land." 10 - It does not include associated interests from which income is derived but which have no direct relation to the producing operation. ${ }^{108}$

The depletion allowance is a single allowance that must be apportioned among the owners of economic interests who are entitled to participate therein. ${ }^{100}$ This is incorporated in the code requirement "excluding .... an amount equal to any rents or royalties paid or incurred by the taxpayer in respect of the property."110 Royalty in this sense is a generic term, including not only the interests ordinarily classified as royalty, such as landowner's royalty, lessor's royalty, overriding royalty, but also net profits interests, ${ }^{111}$ and production payments. ${ }^{112}$

Although percentage depletion for oil and gas is computed as $271 / 2$ per cent of the gross income, there is a limitation that it shall not exceed, 50 per cent of the taxable income from the property. ${ }^{113}$ Taxable income from the property is defined as "gross income from the property" ... less allowable deductions (excluding any deduction for depletion) which are attributable to the mineral property, including allowable deductions attributable to ordinary treatment processes and mining transportation, with respect to which depletion is claimed. These deductions include administrative and financial overhead, operating expenses, selling expenses, depreciation, taxes, losses sustained, etc. In the case of oil and gas properties, such deductions include tangible drilling and development costs . . "114 Thus, deductions must be made for interest

103 Kirby Petroleum Co. v. Commissioner (1945) 148 F. (2d) 80. "The allowance of percentage depletion is made only to the persons who would be entitled to claim cost depletion on account of their ownership of a depletable capital asset, the fundamental theory of the allowance not having been altered by the provisions for percentage depletion."

104 Treas. Reg. 1.613-3(a); Kirby Petroleum Co. v. Commissioner (1945) 148 F. (2d) 80. Gross income from the property . . means gross income from the oil and gas." G.C.M. 22730, 1941-1 C.B. 214. ". ' 'gross income from the property' in the depletion provisions is confined to the gross income from the extraction of ofl rather than gross income from the tract of land in all its uses."

105 Treas. Reg. 1.613-3(a).

100 Anderson v. Helvering (1940) 310 U.S. 404. "By an outright sale of his interest for cash ... an owner converts the form of his capital investment, severs his connection with the production of oil and gas and the income derived from production, and thus renders inapplicable to his situation the reasons for the depletion allowance." 107 Int. Rev. Code of 1954, Sec. 614(a).

108 Consumers Natural Gas Co. v. Commissioner (1935) 30 B.T.A. 1263 aff'd 78 F. (2d) 161 cert. den 296 U.S. 634-operation of pipe line to transport gas. "The words 'the poperty' clearly refer to the particular property which is being depleted and income from clearly refer to the particular property which is being depleted, and income from the property means only income derived from the operation which is depletion of have been based upon a taxpayer's income from all sources. Instead it is to be computed upon income from the property subject to depletion. Consequently, all income and deductions from or properly allocable to other sources must be eliminated

109 Helvering v. Twin Bell Oil Syndicate (1934) 293 U.S. 312; G.C.M. 22730, 1941-1 C.B. 214,

110 Int. Rev. Code of 1954, Sec. 613(a).

111 Burton-Sutton Oil Co. v. Commissioner (1946) 328 U.S. 25.

111 Burton-Sutton Oil Co. v. Commissioner 119

113 Int. Rev. Code of 1954, Sec. 613 .

114 Treas. Reg. 1.613-4. 
on money borrowed for development, legal and professional fees, association dues, ${ }^{115}$ interest on money borrowed to purchase a producing oil and gas property, ${ }^{116}$ taxes, ${ }^{117}$ officers' salaries and office expenses, ${ }^{118}$ and depreciation on equipment. ${ }^{110}$ Where there are no deductions attributable to the depletable interests in the property, gross income and taxable income as defined herein will be the same.120

The regulations also provide that in arriving at taxable income, deductions for allowable expenses must be allocated between mineral producing activities and other activities and must be apportioned where there are several mineral properties. ${ }^{121}$ Where more than one separatc property is involved, a two stage procedure is necessary, e.g., determine what general costs are attributable solely to mineral producing activities and then apportion these costs among the several mineral properties so that a separate taxable income can be computed for each such mineral property. No method for allocation of expenses between producing and other activities is specified. In arriving at the taxable income for purposes of the depletion allowance, no deduction can be taken, as an expense for the $271 / 2$ per cent of gross income which is the tentative measure of the depletion allowance. ${ }^{122}$

Less well known outside the oil industry perhaps, but of equal importance in the acquisition or transfer of oil and gas interests, are the tax implications of drilling wells-referred to as the intangibles option. Intangible drilling and development costs refer to those expenditures on oil and gas properties which in themselves do not have a salvage value. They include such items as wages, fuel, repairs, hauling, supplies, etc. which are incident to and necessary for the drilling of wells and their preparation for production. The taxpayer has the option to treat these items as current expenses and deduct them in the year they are rendered or capitalize them and depend upon the allowances for depreciation and depletion for their recovery. The election must be made in the first year that such expenditures are made and, once exercised, cannot be changed. If capitalized, the items represented by physical property are returnable through depreciation, and the items not represented by physical property are returnable through depletion. Not included in the option are expenditures for tangible property having a salvage value or expenditures incident to the operation of the wells. The former must be capitalized, and the latter must be expensed. Intangibles are rarely capitalized because this option will return no tax advantage because percentage depletion as pointed out previously is not dependent upon basis representing capital investment. There are limitations on the

\footnotetext{
11: Lumaghi Coal Co. v. Helvering (1942) 124 F. (2d) 645.

11; St. Marys Oil and Gas Company (1940) 42 B.T.A. 270; Sheridan-Wyoming Coal Company, Inc. v. Helvering (1941) 125 F. (2d) -interest and ammortization of bond discount and expense.

117 Grison Oil Corporation (1940) 42 B.T.A. 1117-state income taxes; Holly Development Company (1941) 44 B.T.A. 51-interest on federal income tax deficiencies for previous years: Mirabel Quicksilver Company (1940) 41 B.T.A. 401-capital stock taxes.

119 Rocky Mountain Oil Company (1937) 36 B.T.A. 365.

11:! Crews v. Commissioner (1939) 108 F. (2d) 712 .

1211 Commissioner v. Felix Oil Company (1944) 144 F. (2d) 276-net profits interest: the same situation would normally exist for bonus payments received by a lessor.

121 Treas. Reg. 1.613-4. "Expenditures which may be attributable to both the mineral property upon which depletion is claimed and other activities shall be fairly apportioned. Furthermore, where a taxpayer has more than one mineral property. deductions not directly attributable to a specific mineral property shall be fairly deductions not directly attributable to a specific mineral property shall be fairly
apportioned among the several properties." And see Tennessee Consolidated Coal apportioned among the several

12: Int. Rev. Code of 1954, Sec. 613; Treas. Reg. 1.613-4.
} 
parties entitled to exercise the option. Just as depletion requires the ownership of an economic interest, the option to deduct intangibles requires ownership of operating rights. This requirement excludes owners of royalty interests and production payments.

The taxation frame of reference must also include awareness of the type of income that will be generated in the disposition of oil and gas interests. Implicit in the federal income tax is the conception that the levy is imposed not on a return of capital but on a return of income therefrom. ${ }^{1: !}$ Income, in terms of oil and gas transactions, may be classified as ordinary income and as capital gain. Ordinary income is that derived from operation of the property or dealings in the property not amounting to an absolute disposition thereof. Capital gain is derived from the sale or exchange of property other than that held primarily for sale to customers in the ordinary course of business, that is, there must be a sale or an exchange of a capital asset as defined by the Internal Revenue Code. The determination of whether proceeds are ordinary income or capital gain is not always an easy one to make. Thus, an oil and gas lease is considered as a lease and not a sale of the minerals in place, and the bonus received for its execution is consequently governed by the provisions applicable to ordinary income and not those applicable to capital gain. As noted previously, the depletion allowance is available as an allowance against ordinary income but not upon the sale of oil and gas interests. However, capital gain rates of taxation are less than ordinary income rates after allowance for depletion, so that in a specific transaction a complete disposition by way of sale may be intended.

Thirty-five years ago when the principles of conservation of petroleum were being established lawyers and engineers were each concerned with learning the principles and procedures of the other profession. The hybrid that resulted was referred to as a lawgineer or enginawyer. With the emphasis upon the importance of law, engineering and taxation in reservoir evaluation and financing oil transactions, the composite may be referred to a taxgineer or taxenginawyer.

\section{THE SEARCH FOR CAPITAL}

Oil men in search of capital may be classified generally as conglomerates and independents. The term corporation has been avoided because size and not basis of organization is the distinguishing feature. The conglomerates require large amounts of capital and may look initially to conventional securities-the sale of stocks and bonds. Variable forms will be utilized to attract investments that might otherwise flow to nonoil ventures. Thus bonds may carry options for conversion to common stock of the issuing company or of designated other companies. Debentures may be combined with an offer of shares or warrants to induce purchases by large corporate investors such as insurance companies. Financing within the oil industry through farm-outs, production payments and other forms of acquisition or disposition of oil and gas interests is also utilized but these are peripheral to the search for large amounts of capital within the investment markets generally.

123 Burnet v. Logan (1931) 283 U.S. 404. 51 S. Ct. 550, 75 L. Ed. 1143. And see Bloomenthal. $A$ Guide to Federal Oil and Gas Income Taxation (1954) 8 Wyo. L.J. 83. 
The independent is an innovator in his search for capital and the range of innovation increases with the risk potential of the venture. If production has been obtained and funds are needed for development, bank loans to be repaid from production over a three to five year period may be available. If a series of wildcat wells are contemplated, the dollars of equally venturesome investors with incomes taxable in the higher tax brackets may be the only source of funds. Preoccupation of large companies with international or offshore projects may also attract funds to smaller, domestic operations. ${ }^{124}$ If the funds are for development and not exploratory programs, the sources of investment are more numerous.

\section{E. FINANCING TECHNIQUES}

There are so many variables-from purposes to parties, from rights to regulation, from security of investment to risk potential, that the form of an oil and gas financing transaction is limited only by the ingenuity of the creator. However, several patterns have developed and modifications are tailored to the demands of particular investors.

In a general way, each oil and gas lease is a financing transaction. The potential lessee negotiates with the landowner for the terms of the lease-bonus, rental and royalty. Although standardized for particular areas, these elements are the subject of negotiation. Thus a landowner may desire the bonus payable in yearly installments for possible tax savings and the lessee may agree to a higher royalty or a production payment in place of a bonus-particularly in wildcat territory. The lessee may then reduce the cash outlay for drilling costs by conveying a share in the working interest to the drilling contractor.

Exploratory programs of conglomerates depend upon the allocation of funds representing earnings or procured from the sale of equity or debt securities. However, there is extensive "field negotiation" where activities of other oil prospectors is evident. Thus, a company with extensive leases may contract to farm-out a portion of its acreage in return for the drilling of a well and access to all information that is procured in the drilling of the well. If the inducement of a transfer of lease rightsusually on a checkerboard pattern-is insufficient, the company may agree to contribute to the cost of drilling the well if it is drilled to a specified depth (bottom hole agreement) or only in the event that the well finds no production (dry hole agreement). This is an inexpensive way to secure a test of the immediate area. The agreement may also contain an operating agreement-that is, the company or the farm-out

124 "Prospects for the independent oil operator are brighter for 1969 than they have been in years. If he fails this coming year to start dealing, drilling, and producing with some of the old spirit, he will miss a fine chance to regain a sufficient role in the business. Several trends are brightening his outlook. For one thing, money is the business. Several trends are brightening his outlook. For one thing, money is available again for exploration. Investment funds found the oil industry an interesting place last year for risk capital. The trend is expected to increase this
year. This type of financing is a boon for the independent. It cuts his money costs in a period of tight money, spreads his individual risk, and allows him to test more possible oll/gas targets. Several substantial funds are reported planning to earmark big blocks of capital for these ventures. This should give stability and expert financial management to the money transfusion. Another opportunity for the independent arises from the preoccupation of the major companies with expensive
projects offshore and abroad. These companies are funneling an increasingly large projects offshore and abroad. These companies are funneling an increasingly large percentage of capital spending into these areas. This leaves the door open for independents to work up better farmout deals, buy small producing properties that in new areas." Editorial, Signal is 'Go' in ' 69 for independent oil men, Oil and Gas Journal, December 30, 1968. 
assignee may obtain the right to operate the well or wells drilled as producers and account to the other party for the share of production less expenses but retain the right to the oil. The farm-out is also utilized by independents but usually the independent is the party taking the farm-out either because the conglomerate is interested in other areas of operation or because of lower costs of operation. ${ }^{125}$

Oil capital of investors outside the oil industry is a prime source for exploratory activities. Sufficient capital in the amounts required for an extensive exploratory program may be available from a single source, e.g., a single investor or a pension trust. However, several investors, particularly individuals in high tax brackets, may be willing to contribute $\$ 25,000$ to $\$ 100,000$ each. After the potential investors have been found, the technique utilized is the formation of an investment group. One approach is to secure contributions for operations during a specified period-usually a calendar year. Leases are acquired or farm-outs obtained and wells are drilled. To secure for each investor the ownership of an economic interest and of operating rights in order that each investor will be entitled to the depletion allowance and the deduction for intangibles, and to simplify conveyancing problems, title is usually transferred to a corporate nominee which exercises no powers except holding title for the various interest owners. The corporate nominee is the mere conduit for funds received and disbursed-sending to each owner his part of the income from production without deduction for any expenses incurred and billing each owner for his share of expenses, Care must be exercised to avoid giving the corporate nominee any powers of management or control so that it will not be classified as an association taxable as a corporation in which event the corporation and not the individual investors will take the depletion allowance and the deduction for intangibles. Each investor has the option to contribute to a similar investment group in each succeeding calendar year but for purposes of investment, operation and taxation each year is treated as a separate investment unit and not merged with prior or succeeding ones.

Developmental programs are attractive investments where security of collateral is a major factor. ${ }^{12 "}$ Comprehensive conservation laws have reduced the uncertainty of production by limiting application of the Rule of Capture and wasteful methods of production. Oil in place in the reservoir is an acceptable form of security for a loan provided there are sufficient proven reserves for an acceptable ratio of value of the deposit

125 "There are still many areas for even the small independent to explore, if he has sufficlent capital on which to wildcat. No one in the oil industry needs to be reminded that there are many prospects a major company cannot afford to consider which can prove profitable for the independent.

Even in South Texas, the independent can find territory to drill where the risk is justified, especially since the major companies are concentrating on of shore operations. But with the rising drilling costs, today's independent requires some additional avallable cash in order to carry on much exploration. A price increase would supply both some risk capital and incentive.

would supply both some risk capital and incentive. The Independent ollman's prime competitors are not the major companies, but
the challenges of petroleum geology. His problem is to stay competitive and discover the challenges of petroleum geology. His problem is to stay competitive and discover economic oll pools with a minimum of fruitless hunting. Major oil companies are many of them are no longer interested in large sections of the oil producing states." Fitzgerald, Oil Enters the age of the True Professional, Oil and Gas Journal, 37 (December, 1968).

126 "The primary concern of a lending institution is that there are sufficient hydrocarbon reserves to serve as collateral, and that they will be produced at an economic rate in a reasonable period of time." Campbell, Oil Property Evaluation 6 (1959). 
to the amount of the loan.' ${ }^{\prime \prime i}$ Mutual funds have also found development programs attractive to investors and when combined with a partnership agreement among investors to obtain ownership of economic interests and operating rights, it is especially attractive. Banks are a major source of funds for development loans which may be for a specified number of wells or of the open end type-the loan of a specific amount and an agreement to loan more if drilling operations indicate further wells may be producers.

The acquisition of producing properties has become a significant aspect of oil and gas financing. The decline in exploratory activity has been attributable in part to the policy of increasing proven reserves by purchase of productive properties rather than the search for new oil. An example of the fusion of all elements of oil and gas financingrights, reservoir and regulation is the A-B-C transaction. This involves the sale by an operator, $A$, to a purchaser, $B$, but with a reservation by party $A$ of an interest bearing oil payment which is, in turn, sold to an independent third party, C. It is specifically provided in the oil payment that all ad valorem, production, or other taxes shall be paid by the operator and not computed in the payments made to the owner of the oil payment. Party $B$ can usually acquire the property for a relatively small cash outlay, and party $\mathrm{C}$, who is an investor, can borrow up to the face value of the oil payment at a rate of interest that is less than the interest payable by party $B$ on the oil payment itself. This difference between the interest payable on the oil payment and the interest payable on the loan which is secured by the oil payment represents the profit of the investor, party $C$.

There are many variations of this basic transaction. The purchase by $\mathrm{B}$ and $\mathrm{C}$ may be simultaneous transactions. Where $\mathrm{A}$ desires to be paid in cash, party $\mathrm{C}$ may purchase the property and assign the operating rights to $\mathrm{B}$. Where the sale is negotiated through a broker, an intermediate corporation is normally used. To facilitate such transactions, commitment letters are procured from the lending agency by party $\mathrm{C}$ before the sale is made. These are simply agreements by the bank or insurance company to loan a specified amount before a specificd date and outlining the conditions upon which the loan will be made.

The tax advantages available under the A-B-C transaction reflect the importance of the property interests that are transferred. Thus, production payments may be created by transfer of the working interest and the reservation of the right to production payable from a specified fraction of the working interest which is transferred. Or they may be created by "carving" them out of the working interest which is retained, i.e., transferring the right to production payable from a specified fraction of the working interest but retaining the working interest itself. If a production payment is "carved out", the proceeds received by the creator are ordinary income and the depletion allowance may be taken on the proceeds. But if the working interest is transferred and a production payment retained, the proceeds received for the transfer of the working interest are for the sale of an asset and taxable at capital gain rates and no depletion allowance is available on the proceeds. Inasmuch as

127 Supra, n. 48. 
capital gain rates are lower than ordinary income rates even though the latter may be reduced by the depletion allowance, the form of the transfer from $A$ to $B$ is very important. The sale may be less attractive to $A$ if the capital gains treatment of the proceeds is not available.

The A-B-C transaction may become less popular because of an impending change in the regulations of the Internal Revenue Service. As we have seen, the deduction for intangibles may be taken only by the owner of operating rights and only to the extent of his ownership of operating rights. Thus, if the owner of a $50 \%$ interest in the operating rights is obligated to pay $100 \%$ of the costs of operation, that is to carry the other operating interest owner, he may deduct as expenses only $50 \%$ of the intangibles and must capitalize the remainder and recover them through the allowance for depletion. Until recently, the owner of the operating rights in the A-B-C transaction, party $\mathrm{B}$, has paid all costs of operation and has been able to deduct all intangibles even though all of the production except that necessary to pay the costs of operation have been paid to party $C$, to satisfy and retire the production payment. Under the proposed regulations, party $B$ will not be allowed to deduct the intangibles attributable to the fraction of production earmarked for satisfaction of the production payment.

\section{F. FINANCING PROCEDURES}

The execution of a financing plan is a complex process. Requirements vary of course with the scope and type of financing-whether exploratory or developmental, whether to develop properties or dispose of them. Illustrative of the complexity are the procedures utilized by a bank when considering an application for a development loan. Banks which extend this type of financing have a petroleum or natural resources department staffed with geologists, petroleum engineers, possibly economists and other technical personnel who can evaluate the credit worthiness of the oil and gas deposits offered as security for the loan. If the volume of oil loans does not justify an extensive staff, consultants are employed. All of the factors involved in the evaluation of a reservoir will be considered in detail by this technical staff and the bank attorney will determine the validity of title of the properties to be offered as security and prepare or review the loan agreement. The promissory note must be secured by a mortgage or deed of trust, or in the alternative, by the assignment of a production payment or of the oil properties themselves, together with an assignment of the oil runs-the production which is subject to a current contract of sale (division order) and an authorization to substitute the bank for the borrower (transfer order). Normally the bank is not interested in an assignment of the properties themselves because of the operational problems that may result in case of default.

\section{G. CONCLUSION}

Financing of oil and gas transactions is like the law itself-a seamless web. An evaluation of all criteria is necessary in each instance and the ultimate form of the transaction will require negotiation, with price 
as only one of several variables. Perspective in all phases of the undertaking is necessary in order that one factor will not be given undue weight, for example, tax considerations to the detriment of the ownership interests that may be acquired or retained. Financing is fluid under all circumstances but when oil and gas is the object of financing, it becomes volatile and all precautionary measures available must be utilized. 